\title{
Effects of two types of low impact physical training on screen time among overweight adolescents
}

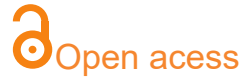

${ }^{1}$ Grupo de Pesquisa em Atividades Aquáticas e Terrestres - GPAT ESEFID - UFRGS

${ }^{2}$ Escola de Saúde e Bem-Estar Faculdade de Desenvolvimento do Rio Grande do Sul - FADERGS

\section{Corresponding author:}

nspoa@yahoo.com.br

Manuscript received: August 2017

Manuscript accepted: October 2017

Version of record online: December 2017

\author{
Rafael de Lima Magalhães ${ }^{1}$, Natalia Soares dos Santos ${ }^{1}$, \\ Roberto Fernandes da Costa ${ }^{2}$, Vitória Bones ${ }^{1}$, Luis Fernando \\ Martins Kruel ${ }^{1}$
}

\begin{abstract}
Introduction: The time that adolescents spend in front of some screen as TV, computer, video games and mobile phones, has been considered a risk factor for obesity and non-communicable chronic diseases.
\end{abstract}

Objective: To analyze the effectiveness of two types of low impact training on the screen time and the BMI of overweight adolescents.

Methods: Forty-seven adolescents were allocated into three groups: control group (CG); water aerobics group (WG); and rebound training group (RG). The three groups had a weekly session of nutritional guidance; additionally, WG and RG trained 12 weeks with three weekly sessions ranging between 24 and 32 minutes, according to the stage of the training periodization with water aerobics and rebound classes, respectively. Anthropometric measurements were performed, and screen time through a questionnaire created for this study in order to identify the amount of hours that adolescents passed in front of a screen. The questionnaire was carried out before and after the training period, as well as anthropometric assessments.

Results: There was no difference pre and post-intervention in screen time for the three groups, however, there was a decrease in BMI in both exercise groups of the pre-training period for posttraining.

Conclusion: There was no reduction of the screen time, however the BMI decreased in the exercise groups.

Keywords: adolescents, obesity, screen time, hydrogimnastic, rebound training 


\section{INTRODUCTION}

A recent study showed that there are over two billion obese people around the world, while in 1980 there were 857 million ${ }^{1}$, including children and adolescents ${ }^{2}$. This increase in the prevalence of obesity in childhood and adolescence has exacerbated the emergence of chronic, non-communicable chronic diseases obesity-associated ${ }^{3}$, while the risk of obesity accompanying the individuals until adult life decreases their life expectancy ${ }^{4}$.

There are several causes to the emergence of obesity. It can be from endogenous origins (related to genetic, neuropsychological, endocrine and/or metabolic components), which are responsible for at least $5 \%$ of cases; or from exogenous origin (influenced by external factors of behavioral, dietary and/ or environmental origin), which are responsible for most $\operatorname{cases}^{5,6}$. Therefore, life habits such as low levels of physical exercise and inadequate diet, associated with a sedentary lifestyle, are the most referred causal factors in the literature ${ }^{7-11}$.

Increasing rates of technology use have direct relationship with the increase of sedentary lifestyle rates, a risk

\section{METHODS}

\section{Criteria}

The sample was selected in a non-random way, by volunteers. The samplewas selected bymeans ofadvertisements in large circulation newspapers of the city of Porto Alegre (Diário Gaúcho, Jornal do Comércio, Metro e Zero Hora), and in schools near the place where the interventions were held.

All parents, or legal guardians, of the adolescents who agreed to participate in the study signed a free, and informed, consent form in the first meeting, the adolescents also signed the consent form.

Forty-seven adolescents aged between 10 and 19 years old, of both sexes, who were overweight or obese, in addition to presenting waist/height ratio greater than 0.50 , were included in the study. Nutritional status was defined according to the BMI by age and sex, as proposed by the World Health Organization (WHO) for adolescents aged between 10 and 19 years old, and the 85 and 97 percentiles were adopted as cut-off points to identify overweight and obese adolescents, respectively ${ }^{18}$.

Exclusion criteria were: pregnancy throughout the training, disability preventing physical exercise practice, and use of medication that could interfere in the present study results, such as medication for cholesterolemia control or for hormonal and diuretic treatments. Those adolescents who achieved less than $80 \%$ exercise frequency throughout the physical training period were also excluded from the analysis.

Randomisation sequence, in parallel, was generated by the online system https://www.randomizer.org, and the sample was stratified by sex in each group after the accomplishment of all pre-intervention assessments.

\section{Data collection}

Data collection was performed at the School of Physical Education, Physiotherapy and Dance of the Federal University of Rio Grande do Sul (ESEFID/UFRGS), always in the afternoons.

All participants were submitted to anthropometric assessments of body mass and height, for further calculation of behavior that can cause serious damage to health ${ }^{12}$. The increase in the prevalence of the sedentary lifestyle, mainly due to the proliferation of technology within the routine of the population, with the increasingly exacerbated use of cell phones, videogames, television and computer, in combination with a continuously less healthy diet and an inefficient physical education in the schools, are issues that deserve attention ${ }^{13}$.

This time spent with technology use is known as screen time and, according to some studies, has a relationship with obesity in adolescence ${ }^{14-16}$, since it is considered a sedentary activity in which the energy expenditure is minimal.

Screen time can be considered as a modifiable risk factor, related to lifestyle and the occurrence of obesity. Decreasing the sedentary lifestyle can lead to a reduction in body mass index (BMI): thus, even if screen time is not altered, physical inactivity and sedentary lifestyle behaviors can be changed ${ }^{17}$.

Therefore, the aim of this study was to analyse the efficiency of two types of low impact physical training on screen time and BMI in overweight adolescents.

the BMI, as well as verification of sexual maturation stage and screen time, before and after the 12 weeks of the intervention period.

Screen time assessment was performed by means of a questionnaire created for the present study, based on instruments used in the literature, in order to identify the number of hours that the adolescents spent in front of a screen - television, computer, videogame, and cell phone. The questionnaire used can be obtained from the website: http:// www.robertocosta.com.br/si/site/0013.

\section{Intervention}

The 47 adolescents were randomly distributed into one of three interventions. One group performed 12 weekly sessions of nutritional orientation (NO), as well as participated in a social network with the aim to stimulate them with advice about healthy habits (CG). The other two groups, in addition to carrying out the same weekly orientation program, performed three weekly sessions of water aerobics (WG) or rebound (RG) classes, both divided into warm up, an aerobic main part, and relaxation, for 12 weeks, training on the same schedules, at the same time, with the same teacher.

The study was approved by the Ethics Committee in Research of the Clinicas Hospital of Porto Alegre (HCPA), under the number 14-0485.

\section{Statistical Analysis}

Baseline descriptive statistical analysis, with mean and standard deviation of the variables of interest, was performed, and the comparisons between sexes were performed by means of Student's t-test for independent samples.

For analysis of screen time data, Generalized Estimating Equations (GEE) were used for comparisons between groups and times, as well as group*time interaction, and Bonferroni post hoc test was used for verification of the differences.

The analyses were performed using SPSS package version 20.0, and the statistical significance adopted was $\alpha=$ 0.05 . 


\section{RESULTS}

The intervention program had 47 adolescents. Baseline comparison between the sexes for variables in sample characterization was performed. There were no significant differences; thus, further analyses were conducted without stratification by sex (Table 1).

After 12 weeks of intervention, there was no difference in screen time between groups from preintervention to post-intervention, or between the times for the three groups, for both weekdays and weekend days; however, it is important to highlight the reduction found in the BMI of the groups that performed 36 sessions of water aerobics or rebound training (Table 2).

Table 1: Sample characterization expressed in means + standard deviation

\begin{tabular}{|c|c|c|c|c|c|c|c|}
\hline & \multicolumn{2}{|c|}{ Total $(n=47)$} & \multicolumn{2}{|c|}{ Male $(n=20)$} & \multicolumn{2}{|c|}{ Female $(n=27)$} & $p$ \\
\hline Age (years) & \multicolumn{2}{|c|}{$13.5 \pm 2.3$} & \multicolumn{2}{|c|}{$13.1 \pm 1.9$} & \multicolumn{2}{|c|}{$13.8 \pm 2.5$} & 0.229 \\
\hline Body mass (kg) & \multicolumn{2}{|c|}{$81.3 \pm 20.2$} & \multicolumn{2}{|c|}{$83.9 \pm 25.5$} & \multicolumn{2}{|c|}{$89.3 \pm 15.3$} & 0.478 \\
\hline Height (cm) & \multicolumn{2}{|c|}{$158.8 \pm 9.5$} & \multicolumn{2}{|c|}{$160.1 \pm 13.2$} & \multicolumn{2}{|c|}{$157.8 \pm 5.5$} & 0.457 \\
\hline \multirow[t]{2}{*}{ Pubertal Stage } & $B / G$ & $\mathrm{P}$ & $\mathrm{G}$ & $\mathrm{P}$ & $G$ & $\mathrm{P}$ & \\
\hline & $3 \pm 1$ & $4 \pm 1$ & $3 \pm 1$ & $3 \pm 1$ & $4 \pm 1$ & $4 \pm 1$ & \\
\hline
\end{tabular}

$\mathrm{B}=$ breast size, $\mathrm{G}=$ genitals size, $\mathrm{P}=$ pubic hair.

Table 2: Comparison of the inter and intragroups means for body mass index and screen time

\begin{tabular}{|c|c|c|c|c|c|c|}
\hline & Group & $\begin{array}{ll}\text { Pre } & \text { Mean } \\
\text { (standard error) }\end{array}$ & $\begin{array}{lr}\text { Post } & \text { Mean } \\
\text { (standard error) }\end{array}$ & Group & Time & Group* Time \\
\hline \multirow[t]{3}{*}{ BMI } & Control $(n=11)$ & $30.1(1.6)$ & $31.2(1.7)$ & & & \\
\hline & Water $(n=18)$ & $32.8(1.3)$ & $30.9(1.3)$ * & 0.457 & 0.006 & 0.005 \\
\hline & Rebound $(n=18)$ & $31.0(1.3)$ & $29.7(1.2)$ * & & & \\
\hline \multirow[t]{3}{*}{ STDW } & Control $(n=11)$ & $8.4(1.1)$ & $8.8(1.4)$ & & & \\
\hline & Water $(n=18)$ & $6.3(1.1)$ & $6.0(1.2)$ & 0.247 & 0.463 & 0.424 \\
\hline & Rebound $(n=18)$ & $6.2(1.0)$ & $7.4(1.2)$ & & & \\
\hline \multirow[t]{3}{*}{ STWD } & Control $(n=11)$ & $10.5(1.2)$ & $8.9(1.4)$ & & & \\
\hline & Water $(n=18)$ & $6.5(1.1)$ & $6.3(0.8)$ & 0.066 & 0.415 & 0.593 \\
\hline & Rebound $(\mathrm{n}=18)$ & $8.2(1.0)$ & $8.4(0.9)$ & & & \\
\hline
\end{tabular}

$\mathrm{BMI}=$ Body Mass Index; STDW = screen time during the week - hours per day during the week; STWD = screen time during the weekend. ${ }^{*}$ Difference $(\mathrm{p}<0.05)$.

\section{DISCUSSION}

The results found that screen time in the three intervention groups, which were above six hours for both weekdays and weekend days, were much greater than the limits of $<2$ hours indicated in the literature ${ }^{19}$. Nevertheless, results greater than those indicated here were found in other studies recently performed ${ }^{20-22}$.

Nemet et al..$^{23}$ also investigated the effects of 12 weeks of intervention and nutritional counseling, with subsequent follow up at one year, evaluating 26 obese adolescents. There was no reduction in screen time after the 12 weeks. The intervention was performed by means of activities that varied in duration and intensity throughout the program, especially designed with games to encourage enthusiasm and participation of the subjects. Although the three month intervention did not achieve screen time reduction, it resulted in a significant reduction in BMI for the exercise group participants, as in the present study. But it is worth mentioning that, after one year of follow up, there were significant differences in both intervention and control groups regarding screen time, demonstrating that the intervention provoked lifestyle changes in the longterm.

With a longer intervention time of 24 weeks, the study of Maddison et al. ${ }^{24}$ did not show a significant effect either in screen time or in the BMI of the overweight adolescents. This intervention was based on physical activities and diet carried out at home, on the sedentary behavior of the whole family, through home visits and incentives for both physical activity practice and reduction of screen time. The intervention did not present a periodised physical exercise program, demonstrating that both professional orientation and adequate training periodisation are fundamental in relation to exercise.

On the other hand, the 12 week study of Faith et $a l .{ }^{25}$ showed effective results in the reduction of screen time, with an innovative intervention. According to the training protocol, both experimental and control groups should pedal on a cycle ergometer; however, during the period that the experimental group could maintain exercise at an intensity equivalent to $50 \%$ of their $\mathrm{VO}_{2} \max$, an automatic dispositive kept a television on, stimulating them to keep exercising at the desired training intensity. Besides achieving reduction in screen time in the experimental group, they also reduced BMI, unlike the control group which had no requirement of training intensity and increased BMI, even with exercise. 
The study of Decelis et al. ${ }^{26}$ reinforces our findings, providing evidence that European adolescents also spend more than two hours in front of the screen. As the adolescents spend most of their day in school, it is important that in these moments they are stimulated and oriented to perform physical activities to reduce sedentary lifestyle and obesity levels, given that in the current days it is very hard to reduce screen time, due to technological advances and conveniences.

Barros et $a .^{27}$ conducted an intervention with overweight or obese schoolchildren with a computer game called PEGGO for obesity control. The results showed that this game, which makes the participants make movements and perform physical exercise in order to meet the objectives, reduced the BMI of all the participants. That is, this study demonstrates that even if the adolescents do not reduce screen time, games that stimulate them to move around and spend energy can elicit reduction in BMI and improve physical conditions, besides stimulating teenagers to practice some physical activity, even if their screen time does not decrease.

However, awareness and education by means of information are fundamental ${ }^{28,29}$. Although not specifically about screen time, the nutritional education classes attended by the three groups were comprised of general healthy habits, besides specific nutrition issues, aiming to raise questionings about the acquired habits and those that should be followed. In this way, only the information was

\section{CONCLUSION}

Therefore, considering that the interventions with these exercise modalities made these adolescents more physically active, in addition to contributing to BMI reduction, the present study results can contribute to the prescription of exercise programs for overweight adolescents. not enough, since the CG did not reach any improvement. It seems that exercise is essential in the reduction of cardiovascular risk factors, as occurred with WG and RG.

Therefore, the focus for control of cardiometabolic risk factors is fundamental in order to, at least, counterbalance the negative effects of physical inactivity in front of the screen ${ }^{30,31}$. Thus, physical exercise practice is paramount in BMI reduction, as achieved in the present study.

For the main outcome, screen time reduction, the expected result was not found. This, in fact, is difficult in this age group, but the present study demonstrated that with an adequate training periodisation it was possible to achieve reduction of the BMI in overweight adolescents, which can positively impact reduction of cardiometabolic risk factors in this sample, even without reducing screen time.

The present study has some limitation, such as the absence of a probabilistic sample, which makes extrapolation of the results for other adolescents groups difficult. Nevertheless, the random allocation used for the formation of the groups softens such limitation.

One point that deserves to be highlighted is the use of two motivational exercise modalities for obese adolescents, which besides reducing the impact on the joints, has an extremely playful character, allowing greater adherence to the intervention.

\section{ACNKOWLEDGEMENTS}

To CAPES (Coordenação de Aperfeiçoamento de Pessoal do Nível Superior) for the support with masters scholarship.

\section{REFERENCES}

1. Ng M, Fleming T, Robinson M, Thomson B, Graetz N, Margono C, et al. Global, regional, and national prevalence of overweight and obesity in children and adults during 1980-2013: a systematic analysis for the Global Burden of Disease Study 2013. Lancet. 2014;384(9945):766-81. DOI: http://dx.doi.org/10.1016/S0140-6736(14)60460-8

2. Organización Panamericana de La Salud. World Health Organization (WHO). Obesidad, alimentación y actividad física. Washington: 2003. [cited 2016 Ouc 15] Available from:http://www.paho.org/Spanish/gov/ce/spp/spp37-08-s.pdf

3. Raitakari OT, Juonala M, Kähönen M, Taittonen L, Laitinen T, Mäki-Torkko N, et al. Cardiovascular risk factors in childhood and carotid artery intima-media thickness in adulthood: the Cardiovascular Risk in Young Finns Study. JAMA. 2003;290(17):2277-83. DOI: http://dx.doi.org/10.1001/jama.290.17.2277

4. Juonala M, Magnussen CG, Berenson GS, Venn A, Burns TL, Sabin MA, et al. Childhood adiposity, adult adiposity, and cardiovascular risk factors. N Engl J Med. 2011;365(20):1876-85. DOI: http://dx.doi.org/10.1056/NEJMoa1010112

5. Despres JP, Arsenault BJ, Côté M, Cartier A, Lemieux I. Abdominal obesity: the cholesterol of the 21st century? Can J Cardiol. 2008;24(Suppl D):7D-12. DOI: http://dx.doi.org/10.1016/S0828-282X(08)71043-2

6. Després JP, Lemieux I, Bergeron J, Pibarot P, Mathieu P, Larose E, et al. Abdominal obesity and the metabolic syndrome: contribution to global cardiometabolic risk. Arterioscler Thromb Vasc Biol. 2008;28(6):1039-49. DOI: http://dx.doi.org/10.1161/ATVBAHA.107.159228 
7. Vasconcellos MB, Anjos LA, Vasconcellos MTL. Estado nutricional e tempo de tela de escolares da Rede Pública de Ensino Fundamental de Niterói, Rio de Janeiro, Brasil. Cad Saúde Pública. 2013;29(4):71322. DOI: http://dx.doi.org/10.1590/S0102-311X2013000400009

8. Blair SN. Physical inactivity: a major public health problem. Nutr Bul. 2007;32(2):113-7. DOI: http://dx.doi.org/10.1111/j.1467-3010.2007.00632.x

9. Ness AR, Leary SD, Mattocks C, Blair SN, Reilly JJ, Wells J, et al. Objectively measured physical activity and fat mass in a large cohort of children. PLoS Med. 2007;4(3):476-84. DOI: http://dx.doi.org/10.1371/journal.pmed.0040097

10. Leary SD, Ness AR, Smith GD, Mattocks C, Deere K, Blair SN, et al. Physical activity and blood pressure in childhood: findings from a population-based study. Hypertension. 2008;51(1):92-8. DOI: https://doi.org/10.1161/HYPERTENSIONAHA.107.099051

11. Oliveira AMA, Cerqueira EMM, Souza JS, Oliveira AC. Sobrepeso e Obesidade Infantil: Influência de Fatores Biológicos e Ambientais em Feira de Santana, BA. Arq Bras Endocrionol Metab. 2003;47(2):14450. DOI: http://dx.doi.org/10.1590/S0004-27302003000200006

12. Olshansky SJ, Passaro DJ, Hershow RC, et al. A potential decline in life expectancy in the United States in the 21st century. N Engl J Med. 2005;352(11):1138-45. DOI: http://dx.doi.org/10.1056/NEJMsr043743

13. Ekelund U, Brage S, Froberg K, Harro M, Anderssen SA, Sardinha LB, et al. TV viewing and physical activity are independently associated with metabolic risk in children: the European Youth Heart Study. PLoS Med. 2006;3(12):e488. DOI: http://dx.doi.org/10.1371/journal.pbmed.003048

14. Altenburg TM, Singh AS, van Mechelen W, Brug J, Chinapaw MJ. Direction of the association between body fatness and self-reported screen time in Dutch adolescents. Int J Behav Nutr Phys Act. 2012;9(4):16. DOI: http://dx.doi.org/10.1186/1479-5868-9-4

15. Anderson SE, Economos CD, Must A. Active play and screen time in US children aged 4 to 11 years in relation to sociodemographic and weight status characteristics: a nationally representative crosssectional analysis. BMC Public Health. 2008;8(1):366. DOI: http://dx.doi.org/10.1186/1471-2458-8-366

16. Tassitano RM, Tenório MCM, Hallal PC. Revisão sistemática sobre obesidade em adolescentes brasileiros. Rev Bras Cineantr Desempenho Hum. 2009;11(4):449-56.

17. Goldfield GS, Mallory R, Parker T, Cunningham T, Legg C, Lumb A, et al. Effects of open-loop feedback on physical activity and television viewing in overweight and obese children: a randomized, controlled trial. Pediatrics. 2006;118(1):157-66. DOI: http://dx.doi.org/10.1542/peds.2005-3052

18. Onis M, Onyango AW, Borghi E, Siyam A, Nishida C, Siekmann J. Development of a WHO growth reference for school-aged children and adolescents. Bull World Health Organ. 2007;85(9):660-7. DOI: http://dx.doi.org/10.1590/S0042-96862007000900010

19. Laurson KR, Lee JA, Gentile DA, Walsh DA, Eisenmann JC. Concurrent Associations between Physical Activity, Screen Time, and Sleep Duration with Childhood Obesity. ISRN Obes. 2014;(2014). DOI: http://dx.doi.org/10.1155/2014/204540

20. Carson V, Rosu A, Janssen I. A cross-sectional study of the environment, physical activity, and screen time among young children and their parents. BMC Public Health. 2014;14:61. DOI: http://dx.doi.org/10.1186/1471-2458-14-61

21. García-Hermoso A, Marina R. Relationship of weight status, physical activity and screen time with academic achievement in adolescents. Obes Res Clin Pract. 2017;11(1):44-50. DOI: : http://dx.doi.org/10.1016/j.orcp.2015.07.006

22. Rey-López JP, Vicente-Rodríguez G, Répásy J, Mesana MI, Ruiz JR, Ortega FB, et al. Food and drink intake during television viewing in adolescents: the Healthy Lifestyle in Europe by Nutrition in Adolescence (HELENA) study. Pub Health Nutr. 2011;14(9):1563-9. DOI: http://dx.doi.org/10.1017/ S1368980011000383

23. Nemet D, Barkan S, Epstein Y, Friedland O, Kowen G, Eliakim A. Short-and long-term beneficial effects of a combined dietary-behavioral-physical activity intervention for the treatment of childhood obesity. Pediatrics. 2005;115(4):e443-9. DOI: http://dx.doi.org/10.1542/peds.2004-2172

24. Maddison R, Marsh S, Foley L, Epstein LH, Olds T, Dewes O, et al. Screen-time weight-loss intervention targeting children at home (SWITCH): a randomized controlled trial. Int J Behav Nutr Phys Act.2014;11:111. DOI: http://dx.doi.org/10.1186/s12966-014-0111-2

25. Faith MS, Berman N, Heo M, Pietrobelli A, Gallagher D, Epstein LH, et al. Effects of contingent television on physical activity and television viewing in obese children. Pediatrics. 2001;107(5):1043-8. DOI: http://dx.doi.org/10.1542/peds.107.5.1043

26. Decelis A, Jago R, Fox KR. Physical activity, screen time and obesity status in a nationally representative 
sample of Maltese youth with international comparisons. BMC Public Health. 2014;14:664.

DOI: http://dx.doi.org/10.1186/1471-2458-14-664

27. Barros M, Formiga R, Neves A. Exergame Peggo - desenvolvimento de jogos de exercício físicofuncional para auxílio no combate da obesidade infantil. SBC Proc SBGames. 2013; 411-7.

28. Robinson TN. Reducing children's television viewing to prevent obesity: a randomized controlled trial. JAMA. 1999282(16):1561-7. DOI: http://dx.doi.org/10.1001/jama.282.16.1561

29. Bello FPS, Chagas NB, Pinto VLM, Camargo LLAL, Demarzo MMP, Germano CMR. Parental awareness of overweight and obesity: anexploratory study addressing low-income adolescents in Brazil. J Hum Growth Dev. 25(3):292-296. DOI: http://dx.doi.org/10.7322/jhgd.106000

30. Reuter CP, Burgos MS, Pritsch CV, Silva PT, Marques KC, Souza S, et al. Obesidade, aptidão cardiorrespiratória, atividade física e tempo de tela em escolares da zona urbana e rural de Santa Cruz do Sul-RS. Cinergis. 2015;16(1):52-6. DOI: http://dx.doi.org/10.17058/cinergis.v16i1.6271

31. Munaro HLR, Silva DAS, Lopes AS. Prevalence of excessive screen time and associated factors in a school from a city in the northeast of Brazil. J Hum Growth Dev. 2016;26(3): 360-7. DOI: http://dx.doi.org/10.7322/jhgd.122821

\section{Resumo}

Introdução: O tempo que adolescentes passam em frente a algum tipo de tela como TV, computador, videogames e celulares, tem sido considerado fator de risco para a obesidade e doenças crônicas não transmissíveis.

Objetivo: Analisar a eficiência de dois tipos de treino de baixo impacto sobre o tempo de tela e sobre o IMC de adolescentes com excesso de peso.

Método: Foram alocados 47 adolescentes em três grupos: controle (GC); hidroginástica (GH); e jump (GJ). Os três grupos tiveram uma sessão semanal de orientação nutricional; além disso, o GH e GJ treinaram 12 semanas com três sessões semanais variando entre 24 e 32 minutos, conforme fase da periodização do treinamento, com aulas de hidroginástica e jump, respectivamente. Foram realizadas avaliações antropométricas e do tempo de tela por meio de questionário criado para o presente estudo, a fim de identificar a quantidade de horas que os adolescentes passavam em frente de uma tela. A aplicação do questionário foi realizada pré e pós-período de treinamento, assim como as avaliações antropométricas.

Resultados: Não houve diferença pré e pós-intervenção no tempo de tela para os três grupos, no entanto, houve redução no IMC em ambos os grupos de exercícios do período pré para o póstreinamento.

Conclusão: Não houve redução do tempo de tela, entretanto o IMC diminuiu nos grupos de exercícios.

Palavras-chave: adolescentes, obesidade, tempo de tela, hidroginástica, jump

${ }^{-}$The authors (2017), this article is distributed under the terms of the Creative Commons Attribution 4.0 International License (http://creativecommons.org/licenses/by/4.0/), which permits unrestricted use, distribution, and reproduction in any medium, provided you give appropriate credit to the original author(s) and the source, provide a link to the Creative Commons license, and indicate if changes were made. The Creative Commons Public Domain Dedication waiver (http://creativecommons.org/publicdomain/ zero/1.0/) applies to the data made available in this article, unless otherwise stated. 